\title{
Effect of tropical cyclones on the tropical tropopause parameters observed using COSMIC GPS RO data
}

\author{
S. Ravindra Babu ${ }^{1}$, M. Venkat Ratnam ${ }^{2}$, G. Basha ${ }^{3}$, B. V. Krishnamurthy ${ }^{4}$, and B. Venkateswararao ${ }^{1}$ \\ ${ }^{1}$ Jawaharlal Nehru Technological University, Hyderabad, India \\ ${ }^{2}$ National Atmospheric Research Laboratory (NARL), Gadanki, India \\ ${ }^{3}$ Masdar Institute of Science and Technology, Abu Dhabi, United Arab Emirates \\ ${ }^{4}$ CEBROSS, Chennai, India \\ Correspondence to: M. Venkat Ratnam (vratnam@narl.gov.in)
}

Received: 24 March 2015 - Published in Atmos. Chem. Phys. Discuss.: 5 May 2015

Revised: 8 July 2015 - Accepted: 27 August 2015 - Published: 16 September 2015

\begin{abstract}
Tropical cyclones (TCs) are deep convective synoptic-scale systems that play an important role in modifying the thermal structure, tropical tropopause parameters and hence also modify stratosphere-troposphere exchange (STE) processes. In the present study, high vertical resolution and high accuracy measurements from COSMIC Global Positioning System (GPS) radio occultation (RO) measurements are used to investigate and quantify the effect of tropical cyclones that occurred over Bay of Bengal and Arabian Sea in the last decade on the tropical tropopause parameters. The tropopause parameters include cold-point tropopause altitude $(\mathrm{CPH})$ and temperature (CPT), lapse-rate tropopause altitude (LRH) and temperature (LRT) and the thickness of the tropical tropopause layer (TTL), that is defined as the layer between convective outflow level $(\mathrm{COH})$ and $\mathrm{CPH}$, obtained from GPS RO data. From all the TC events, we generate the mean cyclone-centred composite structure for the tropopause parameters and removed it from the climatological mean obtained from averaging the GPS RO data from 2002 to 2013. Since the TCs include eye, eye walls and deep convective bands, we obtained the tropopause parameters based on radial distance from the cyclone eye. In general, decrease in the $\mathrm{CPH}$ in the eye is noticed as expected. However, as the distance from the cyclone eye increases by 300,400 , and $500 \mathrm{~km}$, an enhancement in CPH (CPT) and LRH (LRT) is observed. Lowering of CPH $(0.6 \mathrm{~km})$ and LRH $(0.4 \mathrm{~km})$ values with coldest CPT and LRT (2-3 K) within a $500 \mathrm{~km}$ radius of the TC centre is noticed. Higher $(2 \mathrm{~km}) \mathrm{COH}$ leading to the lowering of TTL thickness $(2-3 \mathrm{~km})$ is clearly observed. There are multiple tropopause structures in the pro-
\end{abstract}

files of temperature obtained within $100 \mathrm{~km}$ from the centre of the TC. These changes in the tropopause parameters are expected to influence the water vapour transport from the troposphere to the lower stratosphere, and ozone from the lower stratosphere to the upper troposphere, hence influencing STE processes.

\section{Introduction}

Tropical cyclones (TCs) are one of the most dangerous natural and deep convective synoptic-scale systems that occur throughout the tropical region globally (Emanuel, 2005). Every year, they cause considerable loss of life and damage to property. India has a long coastline, which is prone to very severe cyclone formations in the Arabian Sea (AS) and the Bay of Bengal (BoB). Over the Indian region, these TCs occur during the pre-monsoon (April-May), early monsoon (June) and post-monsoon (September-November) seasons (Pattnaik and Rama Rao, 2008). They persist for a few days to weeks and have large convective activity around the eye, with a horizontal scale of hundreds of kilometres. During the developing stage of a TC, a large drop in its central pressure occurs and the most extreme vertical velocities are usually observed. TCs contain large amounts of water vapour, energy, and momentum, and transport water vapour and energy to the upper troposphere and lower stratosphere (UTLS) region. Hence, TCs play a very important role in affecting the thermal structure and dynamics of UTLS. The concentration of the water vapour transported to the stratosphere is controlled by the 
cold temperatures present at the tropopause (Fueglistaler et al., 2009). The lifetime and size of cyclones also might affect the tropopause parameters on the regional scale (Cairo et al., 2008). There could be a possibility that TCs lift and cool the tropopause more than other mesoscale systems (Romps and Kuang, 2009). It is well known that the intensity and frequency of TCs have increased in recent years (Emmanuel, 2005; Webster et al., 2005).

The tropopause, which is the boundary between the troposphere and the stratosphere, plays a crucial role in the exchange of mass, water vapour, and other chemical species between the two atmospheric regions (Holton et al., 1995). Most of these exchanges (water vapour to the lower stratosphere and ozone to the upper troposphere) take place around the tropopause only and as such, it is very important to study and understand the physical processes occurring around the tropopause region. The tropopause itself varies temporally and as well as spatially. Generally, radiosonde data have been used to study the tropopause parameters and their characteristics (e.g. Randel et al., 2000; Seidel et al., 2001); however radiosonde data are not available over oceans, particularly during severe atmospheric conditions like TCs. Thus, obtaining tropopause characteristics during TCs has remained a daunting task. However, the availability of Global Positioning System (GPS) radio occultation (RO) measurements with high vertical resolution, high accuracy and all-weather capability has made it possible to study the tropopause characteristics over the globe including over oceans. Several studies showed that the GPS RO measurements are well suited for studying severe storms (Pommereau and Held, 2007; Corti et al., 2008; Romps and Kuang, 2009; Biondi et al., 2013).

A few studies have been carried out relating TCs to the UTLS as well as tropopause parameters. Studies include the thermal and dynamical structure of UTLS during TC (Koteswaram, 1967), horizontal and vertical structure of temperature in the cyclone (Waco, 1970), temperature and ozone variations in a hurricane (Penn, 1965), troposphere-stratosphere transport and dehydration in cyclones (Danielsen, 1993), UTLS structure during TCs using AIRS and MLS measurements (Ray and Rosenlof, 2007), RO bending angle anomalies during tropical cyclones (Biondi et al., 2011), thermal structure of intense convective clouds derived from GPS RO (Biondi et al., 2012), estimating the TC cloud top height and vertical temperature structure using GPS RO measurements (Biondi et al., 2013), and observations of temperature in the UTLS of tropical weather disturbances (Davis et al., 2014). Note that the above list is only indicative, not exhaustive. Recently Emmanuel (2013) showed that the modulations of cold-point temperatures influence the maximum potential intensity of tropical cyclones and tropical cyclone activity; however, the effect of the deep convection associated with the TCs on the tropopause parameters is not yet fully understood.

The main objective of the present study is to investigate the spatial variation of tropopause parameters such as cold- point tropopause altitude $(\mathrm{CPH}) /$ temperature $(\mathrm{CPT})$, lapserate tropopause altitude (LRH)/temperature (LRT), convective outflow level altitude $(\mathrm{COH})$ and tropical tropopause layer (TTL) thickness with respect to the TC centre during the entire TC period. Vertical structure of temperature and tropopause parameters within a $5^{\circ}$ radius of the cyclone centre during the TC period is also presented. The water vapour variability in the vicinity of TC is also investigated. The details of the data used for the present study are mentioned in Sect. 2. Methodology for obtaining tropopause parameters during the TC period is mentioned in Sect. 3. Results and discussion are presented in Sect. 4. Finally, summary and conclusions drawn from the present study are presented in Sect. 5.

\section{Database}

\subsection{COSMIC GPS RO data}

The temperature profiles obtained from the Constellation $\mathrm{Ob}$ serving System for Meteorology, Ionosphere, and Climate (COSMIC) GPS RO over the BoB during the TC is utilized for the present study. The GPS RO data were downloaded from the COSMIC Data Analysis and Archive Centre (CDAAC) website (http://cosmic-io.cosmic.ucar.edu/cdaac/ index.html). COSMIC GPS RO is a joint Taiwan-U.S. mission which is a constellation of six microsatellites equipped with GPS receivers (Anthes et al., 2008). These satellites were launched in early 2006 and started providing data from April 2006. During the constellation's initial phase, all the six satellites were not fully configured so as to get uniform distribution of occultations. Thus, data from 2007 to 2013 have been used for the present study. It provides 2000-2500 occultations for a day over the entire globe. Details of temperature retrieval from the bending angle and refractivity profile obtained from GPS RO sounding are presented elsewhere (Kursinski et al., 1997; Kuo et al., 2004; Anthes et al., 2008; Schreiner et al., 2007). For the present study we use level 2 atmPrf temperature profiles to calculate the tropopause parameters during the TCs. In addition, we also used CHAllenging Minisatellite Payload (CHAMP) GPS RO data that are available between the years 2002 and 2006. These complete data (2002 to 2013) are used to generate the background climatology of tropical tropopause parameters over the north Indian Ocean. The vertical resolution of the temperature is $200 \mathrm{~m}$ and the accuracy is $0.5 \mathrm{~K}(7-25 \mathrm{~km})$. Note that these data are validated with a variety of techniques, including GPS radiosonde data, and matched very well, particularly in the UTLS region (Rao et al., 2009). 
Table 1. Cyclone name, grade, cyclone intensity (CI) number, period, centre latitude, centre longitude, estimated central pressure, estimated maximum sustained surface wind, and estimated pressure drop at the centre of all the cyclones used in the present study provided by the IMD.

\begin{tabular}{|c|c|c|c|c|c|c|c|c|}
\hline $\begin{array}{l}\text { Cyclone } \\
\text { name }\end{array}$ & Grade & CI no. & Period & $\begin{array}{l}\text { Centre } \\
\text { latitude }\end{array}$ & $\begin{array}{r}\text { Centre } \\
\text { longitude }\end{array}$ & $\begin{array}{l}\text { Estimated } \\
\text { central } \\
\text { pressure } \\
(\mathrm{hPa})\end{array}$ & $\begin{array}{r}\text { Estimated } \\
\text { maximum } \\
\text { sustained } \\
\text { surface } \\
\text { wind }(\mathrm{kt})\end{array}$ & $\begin{array}{r}\text { Estimated } \\
\text { pressure } \\
\text { drop at the } \\
\text { centre } \\
(\mathrm{hPa})\end{array}$ \\
\hline 03B & $\mathrm{CS}$ & 2.5 & 21-26 Jun 2007 & 23.5 & 66 & 986 (25 Jun) & 35 & 6 \\
\hline Gonu & SuCS & 6.5 & 2-7 Jun 2007 & 20 & 64 & 920 (4 Jun) & 127 & 80 \\
\hline SIDR & VSCS & 6 & 11-16 Nov 2007 & 19.5 & 89 & 944 (15 Nov) & 115 & 66 \\
\hline Nargis & VSCS & 5 & 27 Apr-3 May 2008 & 16 & 94 & 962 (2 May) & 90 & 40 \\
\hline Aila & SCS & - & 23-26 May 2009 & 22 & 88 & 968 (25 May) & 60 & 20 \\
\hline Jal & SCS & 3.5 & 4-7 Nov 2010 & 11 & 84 & 988 (6 Nov) & 60 & 18 \\
\hline Giri & VSCS & 5.5 & $20-23$ Oct 2010 & 19.8 & 93.5 & 950 (22 Oct) & 105 & 52 \\
\hline PHET & VSCS & 4.5 & 31 May-6 Jun 2010 & 18.5 & 60 & 964 (2 Jun) & 85 & 36 \\
\hline Laila & SCS & 3.5 & 17-21 May 2010 & 14.5 & 81 & 986 (19 May) & 55 & 15 \\
\hline Thane & VSCS & 4.5 & 25-30 Dec 2011 & 12 & 81 & 970 (29 Dec) & 75 & 30 \\
\hline Nilam & CS & 3 & 28 Oct-1 Nov 2012 & 11.5 & 81 & 990 (31 Oct) & 45 & 10 \\
\hline Phailin & VSCS & 6 & 8-14 Oct 2013 & 17.1 & 86.8 & 940 (11 Oct) & 115 & 66 \\
\hline Madi & VSCS & 4 & 6-12 Dec 2013 & 15.4 & 85.3 & 988 (10 Dec) & 65 & 16 \\
\hline Helen & SCS & 3.5 & 19-22 Nov 2013 & 16.1 & 82.7 & 990 (21 Nov) & 55 & 17 \\
\hline Mahasen & $\mathrm{CS}$ & 3 & 10-16 May 2013 & 18.5 & 88.5 & 990 (15 May) & 45 & 10 \\
\hline Leher & VSCS & 4 & 23-28 Nov 2013 & 13.2 & 87.5 & 980 (26 Nov) & 75 & 26 \\
\hline
\end{tabular}

\subsection{TC best tracks}

We have taken the TC track information (TC best tracks) data from the India Meteorological Department (IMD) for the period 2007 to 2013. Though GPS RO data are available between 2002 and 2006 from CHAMP GPS RO, we have not utilized them for estimating the tropopause parameters during $\mathrm{TC}$, as the number of occultations from this single satellite are too sparse (maximum 250-300 occultations over the entire globe). TC track information includes TC name, dates, centre latitude and longitude, cyclone intensity (CI), and minimum sea level (MSL) pressure of the TC at $3 \mathrm{~h}$ intervals during its formation. During this period (2007 to 2013), around 44 TCs formed over the north Indian Ocean. For the present study, we consider only the TCs whose lifetime is a minimum of 4 days or more. From these 44 TCs, we selected 16 TCs based on their lifetime to investigate the effect of TCs on the tropical tropopause parameters. The tracks of all the TCs used for the present study are shown in Fig. 1 and different colours indicate TCs which occurred in different years. Note that only two TCs formed over the AS and the rest all formed over the BoB. Only one TC that formed over $\mathrm{BoB}$ crossed the Indian land mass and became stronger again when it reached the AS. The details of TC are shown in Table 1, such as name, grade, CI (cyclone intensity) number, as designated by IMD, lifetime, and central latitude and longitude (position) of the cyclone, where lowest pressure and highest wind speed are observed with an estimated pressure

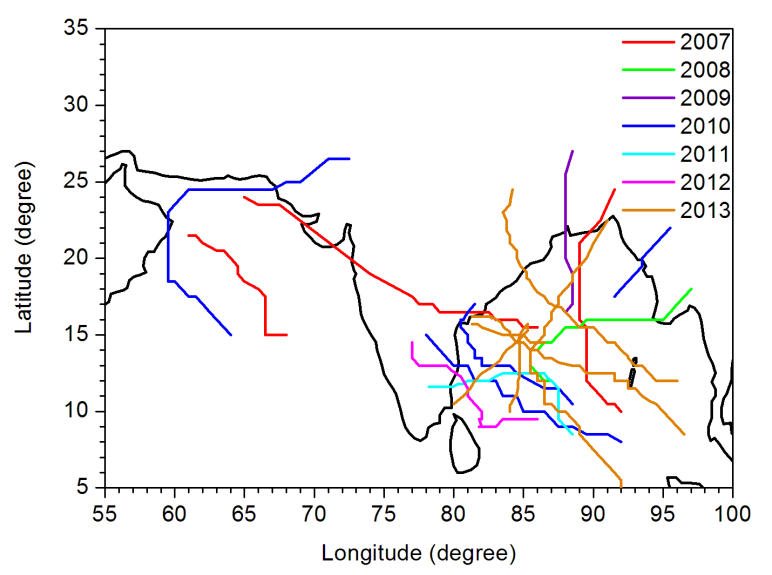

Figure 1. TC tracks with a minimum TC lifetime of 4 days and above used for the present study during 2007-2013 over the north Indian Ocean. Different colours indicate TCs that occurred in different years.

drop. Details of the acronyms used in this table are provided in Sect. 3.2.

\section{Analyses procedure}

\subsection{Estimation of different tropopause parameters}

The tropopause is defined in different ways (Highwood and Hoskins, 1998) and the most commonly used one in the trop- 
ics is the cold-point tropopause. The CPH is defined as the altitude of the temperature minimum that exists between the troposphere and stratosphere. Another one is LRH, defined by the World Meteorological Organization (WMO; 1957) as "the lowest level at which the lapse rate decreases to $2 \mathrm{~K} / \mathrm{km}$ or less, provided that the average lapse rate between this level and all higher levels within $2 \mathrm{~km}$ does not exceed $2 \mathrm{~K} / \mathrm{km}$."

In recent years, the study of the tropopause over the tropics has led to the concept of a tropical tropopause layer (TTL) (Highwood and Hoskins, 1998; Gettelman and Birner, 2007; Fueglistaler et al., 2009), which is the transition region between the convective-radiative equilibrium of the troposphere and the stratosphere. In this transition region, both stratospheric and tropospheric processes interact. The top of the TTL is marked by the CPH and the base by the level of the top of all the major convective outflows, named as the convective tropopause altitude $(\mathrm{COH})$, and the altitude difference between $\mathrm{CPH}$ and $\mathrm{COH}$ is the TTL thickness. A minimum in potential temperature gradients is identified as $\mathrm{COH}$ following Gettelman and Forster (2002). Note that it closely matches with the divergence profile obtained from mesosphere-stratosphere-troposphere (MST) radar observations (Mehta et al., 2008). All these parameters (CPH, CPT, LRH, LRT, COH, and TTL thickness) are estimated for each profile of GPS RO during the entire TC lifetime. In order to estimate the effect of TCs on the tropopause parameters, the background of all the tropopause parameters is obtained by averaging the data from 2002 to 2013 (climatology) with exclusion of the days of the TCs. These climatological values are grouped into $2.5^{\circ} \times 2.5^{\circ}$ grids. There could be day-today to interannual variability in the observed climatological tropopause parameters. Since large data (14 years) have gone through climatology, we assume that variability less than the solar cycle is nullified, if not removed completely.

\subsection{Classification of the TCs}

The effect of the TCs on the tropopause parameters mainly depends on the intensity of the cyclone. Tropical cyclone intensity is defined by the maximum mean wind speed over open flatland or water, sometimes referred to as the maximum sustained wind that will be experienced around the eye wall of the cyclone. The low pressure system over the Indian region is classified based on the maximum sustained wind speed associated with the system, and the pressure deficit/number of closed isobars associated with the system. The pressure criteria are used when the system is over land and wind criteria are used when the system is over the sea (IMD). Based on 10 min maximum sustained wind speed, IMD has defined various stages of the TC. It is named as low pressure when the maximum sustained wind speed at the sea surface is $<17 \mathrm{knots} / 32 \mathrm{kmph}$, as depression (D) at 17-27 knots/32-50 kmph, deep depression (DD) at 28-33 knots $/ 51-59 \mathrm{kmph}$, cyclonic storm (CS) at 34$47 \mathrm{knots} / 60-90 \mathrm{kmph}$, severe cyclonic storm (SCS) at 48-
63 knots/90-110 kmph, very severe cyclonic storm (VSCS) at 64-119 knots/119-220 kmph, and super cyclonic storm (SuCS) at $>119 \mathrm{knots} / 220 \mathrm{kmph}$. As an example, the TC Nargis is chosen to show the different stages of TC and also its pressure and wind speed. The TC Nargis originated as a depression formed over the south-east of the BoB at 03:00 UTC on 27 April 2008. From Table 1 it is clear that this cyclone comes under the category VSCS, which has a CI of 5. The observed IMD track of the VSCS Nargis is shown in Fig. 1 (green line). This system moved slightly north-eastwards and intensified into a cyclone at 00:00 UTC of 28 April. It remained stationary for some time and further intensified into an SCS at 09:00 UTC on 28 April and into a VSCS grade, as classified by the IMD, at 03:00 UTC on 29 April (Pattnaik and Rama Rao, 2008). It moved further eastward and crossed the coast of Myanmar on 2 May at 06:00 UTC.

The IMD-reported maximum wind speed and minimum SLP of the TC Nargis are shown in Fig. 2a. Note that highest wind speed ( $\sim 90$ knots) and lowest pressure $(\sim 960 \mathrm{hPa})$ are evident on 2 May. The interpolated outgoing long-wave radiation (OLR), which is considered a proxy for tropical deep convection, obtained from the NOAA satellite on 28 April 2008, is shown in Fig. $2 \mathrm{~b}$ along with the track of the cyclone provided by IMD. Black circles are drawn to show the $500,1000,1500$, and $2000 \mathrm{~km}$ radius from the TC centre. Note that this cyclone was stationary on 28 April and the minimum OLR (maximum convection) which was as low as $90 \mathrm{~W} \mathrm{~m}^{-2}$, lay over the region within $500 \mathrm{~km}$ and extended to south-east and west side of the cyclone track within $1000 \mathrm{~km}$. The monthly mean $\mathrm{CPH}$ for the month of April is shown in Fig. 2c and a small black circle shows the TC Nargis centre observed on 28 April 2008. An interesting feature to be noticed is the enhancement of $\mathrm{CPH}$ around $25^{\circ} \mathrm{N}$ over the Indian region more than equatorial latitudes, which are well reported earlier (Venkat Ratnam et al., 2005). This feature is commonly observed over the Indian region. Note that latitudinal variation of $500 \mathrm{~m}$ can be observed if we consider $2000 \mathrm{~km}$ from the centre of the cyclone. In order to avoid this latitudinal variation, we hereafter restrict our discussion to within $1000 \mathrm{~km}$ from the cyclone centre.

The COSMIC RO data obtained for each day during the cyclone period are separated based on the IMD cyclone best track data, and the tropopause parameters for each individual temperature profile are calculated. Since IMD-based TC track data are available at $3 \mathrm{~h}$ intervals, we considered the middle of the coordinates (latitude and longitude) of a particular day of the TC as the centre of the TC for that day. Based on these centres, we calculated the distance from the TC centre for each individual RO available on a particular TC day at intervals of $250 \mathrm{~km}$ up to $1000 \mathrm{~km}$. 


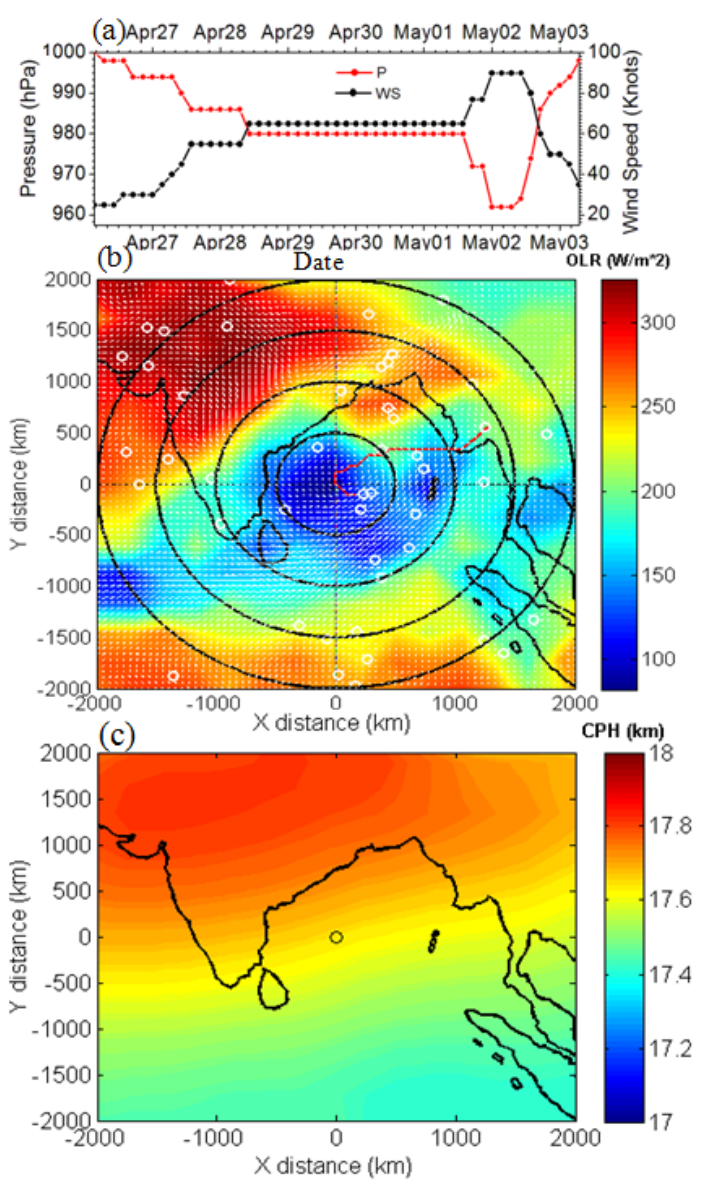

Figure 2. (a) IMD-observed minimum sea level pressure (MSLP; red line) and maximum wind speed (black line) during TC Nargis. (b) TC-centred composite of NOAA OLR observed on 28 April 2008 along with IMD-observed Nargis track (red line). White arrows show the wind vectors obtained from ERA-Interim on the same day. White circles show the COSMIC RO observed on the same day. Black circles are drawn to shown the 500, 1000, 1500 , and $2000 \mathrm{~km}$ distance away from TC centres. (c) Climatology of $\mathrm{CPH}$ for the month of April obtained while averaging from 2002 to 2013. The small black circle shows the Nargis TC centre observed on 28 April 2008.

\section{Results and discussion}

\subsection{Tropopause parameters observed during VSCS Nargis}

The locations of all the COSMIC GPS RO observations on 28 April 2008 are shown (white circles) in Fig. 2b. There were about 13 occultations that occurred within $1000 \mathrm{~km}$ from the centre of the cyclone. All the tropopause parameters mentioned in Sect. 3.1 are estimated for each of these profiles and climatological values were subtracted for estimating the effect of the TCs on the tropopause parameters. A typical example of cyclone-centred tropopause parameters obtained from the COSMIC GPS RO profiles during TC
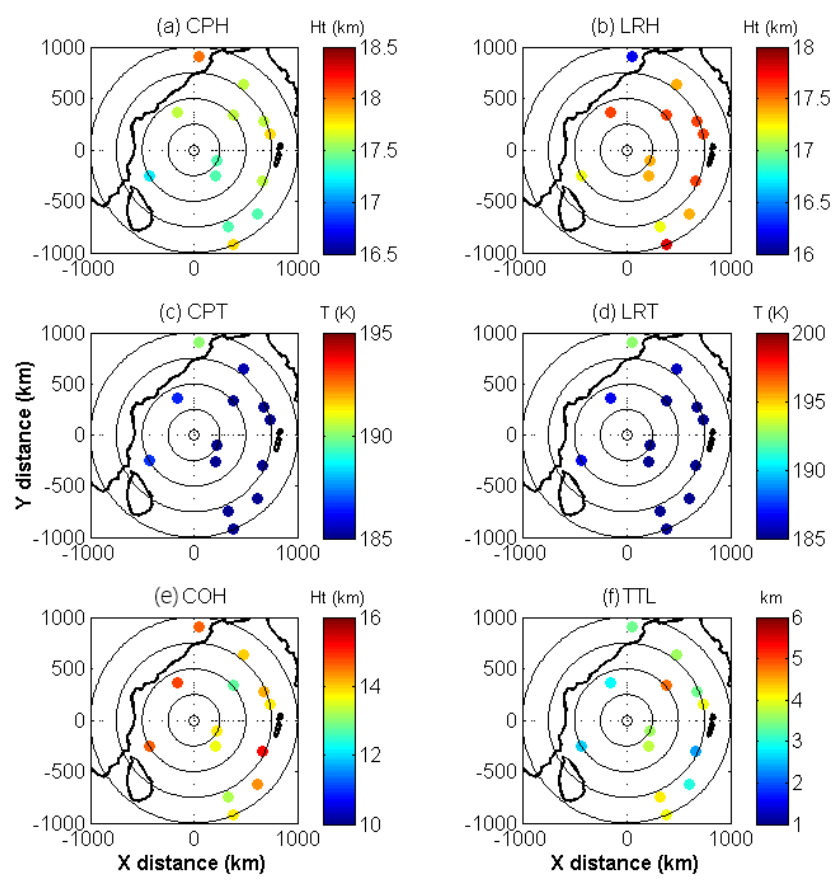

Figure 3. Spatial variation of (a) CPH, (b) LRH, (c) CPT, (d) LRT, (e) $\mathrm{COH}$, and (f) TTL thickness with respect to the centre of cyclone Nargis observed on 28 April 2008 for the RO shown in (b). Black circles are drawn to show the $250,500,750$, and $1000 \mathrm{~km}$ distance away from TC centres.

Nargis on 28 April 2008 is shown in Fig. 3; panel (a) CPH, panel (b) LRH, panel (c) CPT, panel (d) LRT, panel (e) COH, and panel (f) TTL thickness. Black circles are drawn to show the $250,500,750$, and $1000 \mathrm{~km}$ distance away from the TC centres. Though it is difficult to draw any conclusions from this figure as occultations are sparse, it is clear that $\mathrm{CPH}$ and LRH are slightly lower $(\sim 17.25 \mathrm{~km})$ within $500 \mathrm{~km}$, and higher $(>17.5 \mathrm{~km})$ further away from the centre when compared to the CPH and LRH around $1000 \mathrm{~km}$. There is no substantial difference in the CPT and LRT within $500 \mathrm{~km}$ of $\mathrm{TC}$ in this example. However, $\mathrm{COH}$ is a little higher $(\sim 14 \mathrm{~km})$ within $500 \mathrm{~km}$ and slightly lower away from the centre, and TTL thickness is small $(<4 \mathrm{~km})$ within $500 \mathrm{~km}$ from the centre of TC Nargis. This suggests that the TC affects the tropopause parameters. Note that the variations observed from further away than $500 \mathrm{~km}$, mainly over land, can be partly attributed to the latitudinal change itself which will be discussed further in the next sections.

Note that the GPS RO-estimated temperature near the tropopause during cyclone activity is expected to be biased, with the assumption that dry atmosphere as water vapour is sometimes being pumped up to the tropical tropopause. However, note that we could notice a similar change in bending angle and hence refractivity which is combination of temperature and water vapour. In the simulations reported in Rao et al. (2009), one can notice that a change in the temperature 
is not that sensitive when compared to the pressure and water vapour. Since the changes are found to be up to 4-5 K, we expect these are meaningful, even after considering expected larger bias during disturbed weather conditions. More details of COSMIC temperature during the cyclone period can be found in Biondi et al. (2011).

\subsection{Spatial variations of tropopause parameters from the centre of the TC}

In this subsection, the spatial variations of tropopause parameters from the cyclone centre for different intensities of TC are presented. From the example of Nargis it is clear that we have a fewer number of occultations for a single TC day and hence it is difficult to describe the tropopause characteristics away from the TC centre. In order to obtain more data points for statistically significant results, we have separated COSMIC RO data based on TC intensity from all 16 TCs. When we separated these based on TC intensity with respect to their distance from the TC centre, there are 381, 727, 1124, 481, and 865 occultations for D, DD, CS, SCS and VSCS, respectively. From these profiles, we made a $250 \mathrm{~km} \times 250 \mathrm{~km}$ grid of tropopause parameters based on the TC centre for all TC intensities. After going through the detailed analysis, no significant difference in the tropopause parameters between $\mathrm{D}$ and DD or CS and SCS was noticed. So, we have combined the observations obtained during those periods. Since there is no significant difference in the tropopause parameters during $\mathrm{D}$ and DD we have not shown these here.

Figure 4 shows the cyclone-centred composite of panel (a) CPH, panel (b) LRH, panel (c) CPT, panel (d) LRT, panel (e) $\mathrm{COH}$, and panel (f) TTL thickness for the cases of $\mathrm{CS}$ and SCS. From the figure it is clear that the south-west side of the area up to $1000 \mathrm{~km}$ radius from the TC centre the CPH (Fig. 4a) and LRH (Fig. 4b) is lower than the north side of the TC centre. However, colder tropopause temperatures are clearly observed within $1000 \mathrm{~km}$ in the case of CPT (Fig. 4c) and LRT (Fig. 4d). A $10 \mathrm{~K}$ difference in the CPT and LRT can be noticed from the TC centre to the north side. Very interestingly $\mathrm{COH}$ is much higher over $1000 \mathrm{~km}$ and also towards the south side of the TC centre, with a maximum altitude of around $15 \mathrm{~km}$ (Fig. 4e) leading to a smaller TTL thickness (Fig. 4f). Note that TTL thickness is less than $3 \mathrm{~km}$ within $500 \mathrm{~km}$ from the centre of the TC and up to $1000 \mathrm{~km}$ on the southern side. These different variations in the tropopause parameters might be due to two reasons. One may be due to the distribution of convection during the developing stages of TCs, such as depression and deep depression on the south side of the TC centre which moved to the north-west side. Another reason, at least in part, can be attributed to the latitudinal variation; however, we found very low values of $\mathrm{CPH}$ within a $500 \mathrm{~km}$ radius of the TC centre. Similar variations are observed when we separated the TC based on different intensities (figures not shown). Thus, in general, we observed a lowering of $\mathrm{CPH}$ and $\mathrm{LRH}$ values
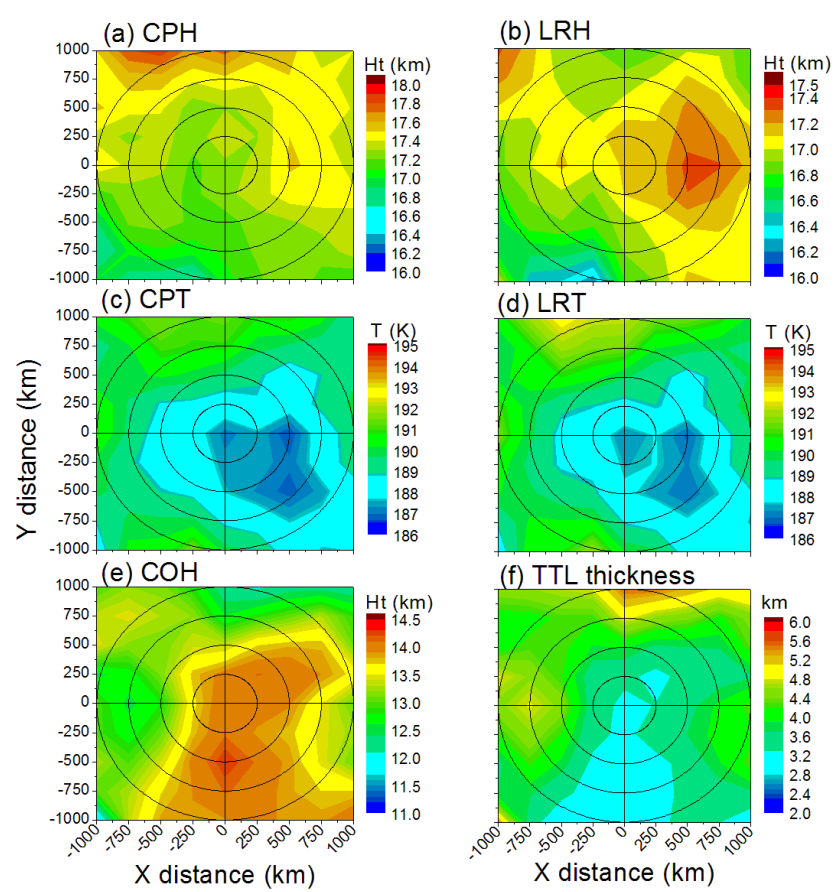

Figure 4. Cyclone-centred composite of (a) $\mathrm{CPH}$, (b) $\mathrm{LRH}$, (c) CPT, (d) LRT, (e) COH, and (f) TTL thickness observed during the CS and SCS.

with coldest CPT and LRT within a $500 \mathrm{~km}$ radius of the TC centre. Higher $\mathrm{COH}$ leading to a lowering of TTL thickness is clearly observed. Higher $\mathrm{COH}$ within $500 \mathrm{~km}$ from the TC centre suggests that maximum convective outflow reached higher altitude. At the same time lowering the $\mathrm{CPH}$, leading to the small TTL thickness within the TC centre is observed, probably due to the subsidence. In order to quantify the effect of TCs on the tropopause parameters more clearly we have obtained anomalies by subtracting the tropopause parameters observed during TC from the background climatological tropopause parameters.

Figure 5 shows the mean difference of cyclone-centred tropopause parameters from the background climatology observed in CPH, LRH, CPT, LRT, COH, and TTL thickness. Note that this figure is a composite of the all the tropopause parameters irrespective of the TC intensity. Thus, some differences between Figs. 4 and 5 can be expected. In general, the CPH (LRH) is lowered by $0.6 \mathrm{~km}(0.4 \mathrm{~km})$ in most of the areas within a $1000 \mathrm{~km}$ radius of the TC centre and CPT (and LRT) is colder by $3-4 \mathrm{~K}$. Note that this decrease in the $\mathrm{CPH}$ is not uniform over a $1000 \mathrm{~km}$ radius from the centre. Throughout the area $1000 \mathrm{~km}$ from the centre, the temperature is more or less colder than, or equal to, the climatological value in both CPT/LRT. COH increased up to $2 \mathrm{~km}$ within $500 \mathrm{~km}$ from the TCs and in some areas up to $1000 \mathrm{~km}$. TTL thickness is reduced by $2 \mathrm{~km}$ within $500 \mathrm{~km}$ from the TC centre and over some areas up to $1000 \mathrm{~km}$. Note that this decrease in TTL thickness is not only because of pushing up of 

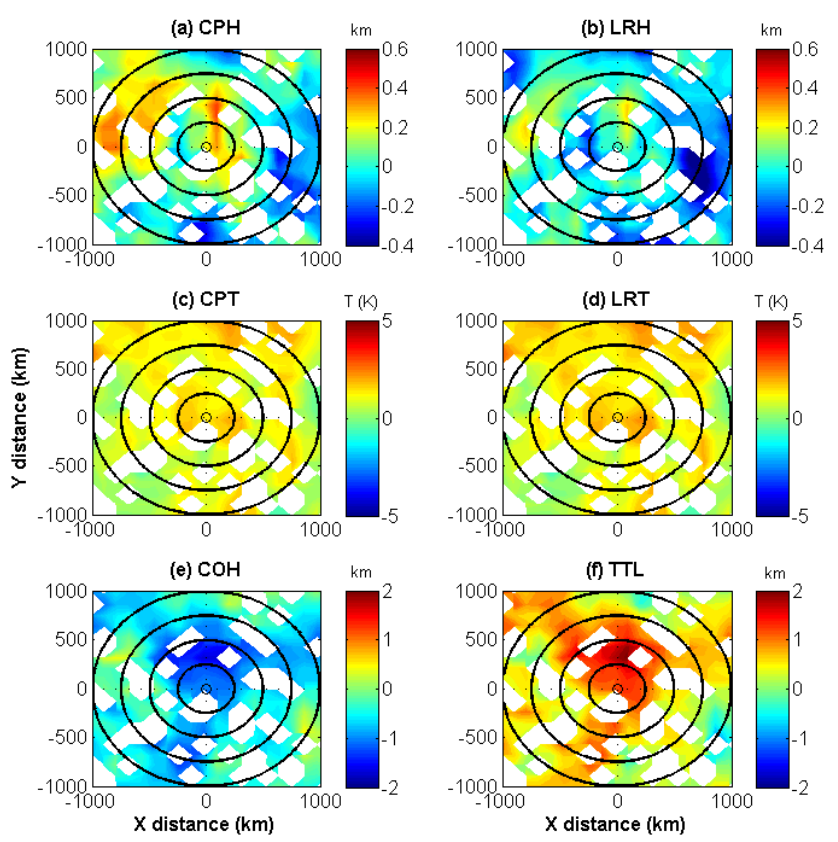

Figure 5. Same as Fig. 4, but for the mean difference in the tropopause parameters between climatological mean and individual tropopause parameters observed during TCs (irrespective of cyclone intensity).

the $\mathrm{COH}$ but also a decrease of $\mathrm{CPH}$. It is worth quoting the recent findings of Biondi et al. (2015) where they reported a decrease in the temperatures of $3-4 \mathrm{~K}$ and a reduction in the TTL thickness to $2-3 \mathrm{~km}$ over the north Indian basin. Our findings match with their reports for the Indian region exactly.

\subsection{Spatial variations of water vapour from the centre of the TC}

Deep convection is expected to reach up to the tropopause altitude and sometimes above it during the TCs, leading to the penetration of water vapour to the lower stratosphere. At the same time, chances of pushing down the ozone from the lower stratosphere, leading to lower CPH (subsidence) is also expected, leading to STE processes. Though not completely relevant to the present study, it is worth recalling recent results by Škerlak et al. (2014), where it was quantitatively shown that maxima of STE are located over the storm (cyclone) track regions in the North Atlantic and North Pacific during all seasons (except summer), with an averaged mass flux of approximately $500 \mathrm{~kg} \mathrm{~km}^{-2} \mathrm{~s}^{-1}$ from the stratosphere to the troposphere and approximately $300 \mathrm{~kg} \mathrm{~km}^{-2} \mathrm{~s}^{-1}$ in the opposite direction. It will be interesting to investigate how these numbers compare for TC over the Indian region. Since GPS RO also provides information on water vapour (Kishore et al., 2011), we have further investigated the effect of TCs on the vertical distribution of water vapour. A cyclone-centred composite of averaged relative humidity $(\mathrm{RH})$ observed dur- ing all the TCs, irrespective of TC intensity, in the $0-5,5-10$, and $10-15 \mathrm{~km}$ layer using COSMIC GPS RO wet profiles is shown in Fig. 6a-c, respectively. Note that above these altitudes, water vapour is not sensitive in the GPS RO measurements. In general, larger $\mathrm{RH}$ values are noticed in the south-eastern side of the TCs in the lower layer $(0-5 \mathrm{~km})$ and throughout the south side of the TC in the $5-10 \mathrm{~km}$ layer. Higher RH is noticed within $500 \mathrm{~km}$ from the TC centre. Interestingly, high $\mathrm{RH}$ values of $70 \%$ or more are noticed on the eastern side of the TC in the $10-15 \mathrm{~km}$ layer. Thus, it is clear that deep convection prevailing during the TC within $500 \mathrm{~km}$ from the centre of the TC can penetrate to the lower stratosphere through the tropopause. The higher $\mathrm{RH}$ values observed in the $10-15 \mathrm{~km}$ layer may be due to the upper level anti-cyclonic circulation over the cyclones. Ray and Rosenlof (2007) reported higher water vapour mixing ratios to the east of the cyclone centre for TCs over the Atlantic and Pacific oceans and found averaged water vapour is enhanced by $30-50 \mathrm{ppmv}$ or more within $500 \mathrm{~km}$ of the eye compared to the surrounding average water vapour mixing ratios. Our results match well with these. Note that Biondi et al. (2015) reported $30-50 \%$ of the time overshooting of convection during TCs, strongly supporting our findings. At the same time, Midya et al. (2012) reported that over BoB and AS, the total column ozone (TOC) decreases steadily before and during the formation of a TC, followed by a more or less increasing trend after dissipation of the cyclone. A very recent case study by Das et al. (2015) also confirms the intrusion of stratospheric air into the upper and middle troposphere during the passage of tropical cyclone Nilam. It will be interesting to see the variability of ozone during the same time for all the cyclones presented here to investigate the STE processes away from the TC centre.

From the above, in general, it can be concluded that the tropical tropopause is significantly affected by TCs. The effect is more pronounced within $500 \mathrm{~km}$ from the centre of the TC. Note that TCs have their eye, eye wall, rain bands, convective cloud tops, strong updrafts, and cirrus deck all occurring in the range of 500 to $1000 \mathrm{~km}$ from the TC centre. From the above results, we expect that a significant effect of the TCs on the tropopause parameters could be felt up to $500 \mathrm{~km}$ from the TC centre. We have further investigated the effect of TCs on the thermal structure of the UTLS region and the results are presented in the next section.

\subsection{Vertical thermal structure of UTLS within $500 \mathrm{~km}$ from the TC centre}

We considered the GPS RO with respect to the IMD best track data and took a $\pm 1 \mathrm{~h}$ time window of co-located RO profiles with respect to IMD best track time for every $3 \mathrm{~h}$. Based on this we calculated the distance from the TC centre. We classified them with respect to the distance from the centre as $100,200,300,400$, and $500 \mathrm{~km}$, respectively. There were 90 GPS RO occurring within $500 \mathrm{~km}$ and when 


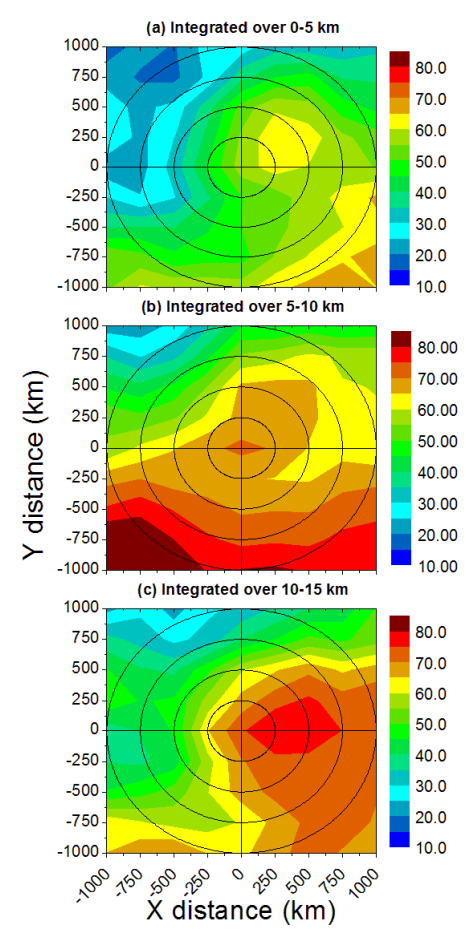

Figure 6. Cyclone-centred composite of averaged RH observed during TCs (irrespective of TC intensity) in the (a) $0-5 \mathrm{~km}$, (b) 5$10 \mathrm{~km}$, and (c) $10-15 \mathrm{~km}$ layer using COSMIC GPS RO wet profiles.

we separated them at $100 \mathrm{~km}$ steps, there were $7,11,20,20$, and 32 profiles, respectively. Figure 7 shows the mean vertical structure of temperature with respect to distance within $500 \mathrm{~km}$ at steps of $100 \mathrm{~km}$ from the TC centre along with the standard error. The enlarged portion in Fig. 7 shows the vertical structure of the temperature within the UTLS region from 16 to $18 \mathrm{~km}$. Here we considered a $\pm 1 \mathrm{~h}$ time window of co-located RO profiles with respect to IMD cyclone best track data for obtaining the thermal structure over the TC period. Note that this is a better time window resolution than the earlier reported $3 \mathrm{~h}$ time window by Biondi et al. (2013) for describing the thermal structure during the cyclone period. In general, no significant difference is evident in the temperature structure within $500 \mathrm{~km}$ from the TC centre below $14 \mathrm{~km}$. This is mainly due to the synoptic nature of convection within a $500 \mathrm{~km}$ radius of the TC centre. Generally, in the troposphere below approximately $14 \mathrm{~km}$, the radiative cooling balances the latent heat release by convection. However, large variation in the mean temperature structure can be noticed above $14 \mathrm{~km}$. This is mainly due to balancing between the radiative heating and the stratospheredriven upwelling above $16 \mathrm{~km}$. Strong updrafts around the eye wall and down drafts, subsidence near the eye, and formation of the cirrus clouds might change the temperature structure in the UTLS region strongly. It is interesting to notice lowering of tropopause altitudes with colder temper-

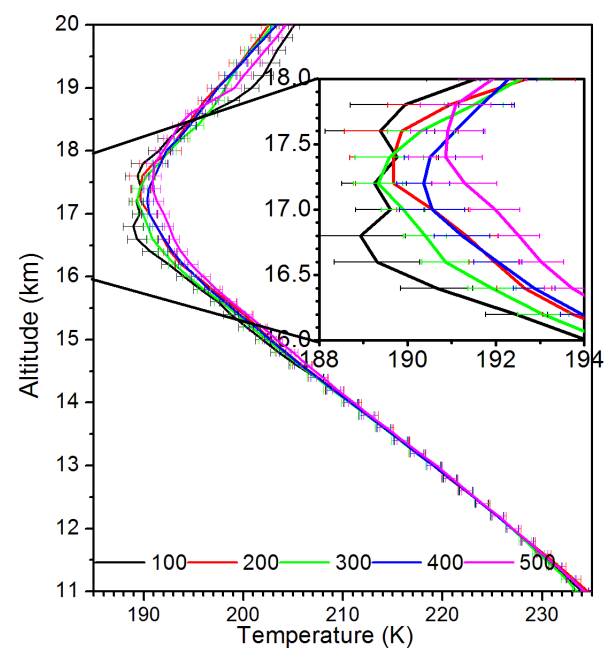

Figure 7. Mean temperature structure observed using GPS RO profiles that occurred within 100, 200, 300, 400, and $500 \mathrm{~km}$ from the TC centre. Horizontal bars show the standard error. For clarity, the temperature structure observed between 16 and $18 \mathrm{~km}$ is shown in the box.

atures in the profiles obtained within $100 \mathrm{~km}$, followed at 300,200 , and $400 \mathrm{~km}$. It indicates that rain bands are of the size of roughly $100 \mathrm{~km}$. There is a temperature difference of $5 \mathrm{~K}$ in the UTLS region in the profiles that occurred within $100 \mathrm{~km}$ from the profiles that occurred further away than $400 \mathrm{~km}$. These are statistically significant differences as the error bars do not mix with each other for the profile that occurred within $100 \mathrm{~km}$ to the rest of the profiles. Warmer temperatures are also visible in the lower stratosphere in the profiles that are obtained within $100 \mathrm{~km}$ when compared to those that occurred further away. Multiple tropopause structures are clearly visible in the profiles that occurred within $100 \mathrm{~km}$ from the TC, though the number of profiles available is small. These multiple tropopauses are similar to double tropopauses observed by Corti et al. (2008), Biondi et al. (2011), and Davis et al. (2014). The cause for these multiple tropopauses might be either due to clouds (Biondi et al., 2013), wave activity, cirrus deck or ozone (Mehta et al., 2011), which demands separate investigation.

We also calculated the tropopause parameters with respect to $100,200,300,400$, and $500 \mathrm{~km}$ distance away from the TC centre, respectively. Figure 8 shows the mean tropical tropopause parameters of $\mathrm{CPH}, \mathrm{CPT}, \mathrm{LRH}, \mathrm{LRT}, \mathrm{COH}$, and TTL thickness observed from the profiles that are available within a $500 \mathrm{~km}$ radius of the TC centre. In general, CPH (CPT) increases (decreases) as we move away from the TC centre within $500 \mathrm{~km}$ (except at $200 \mathrm{~km}$ in the case of CPH) (Fig. 8a). There is a difference of $0.4 \mathrm{~km}(3 \mathrm{~K})$ in the $\mathrm{CPH}$ (CPT) within $500 \mathrm{~km}$ from the centre of the TC. Similar variability in the LRT is observed but not in LRH (Fig. 8b). An inverse relation between LRH and LRT is noticed but not in $\mathrm{CPH}$ and CPT. A nearly $2 \mathrm{~km}$ decrease in $\mathrm{COH}$ is clearly no- 

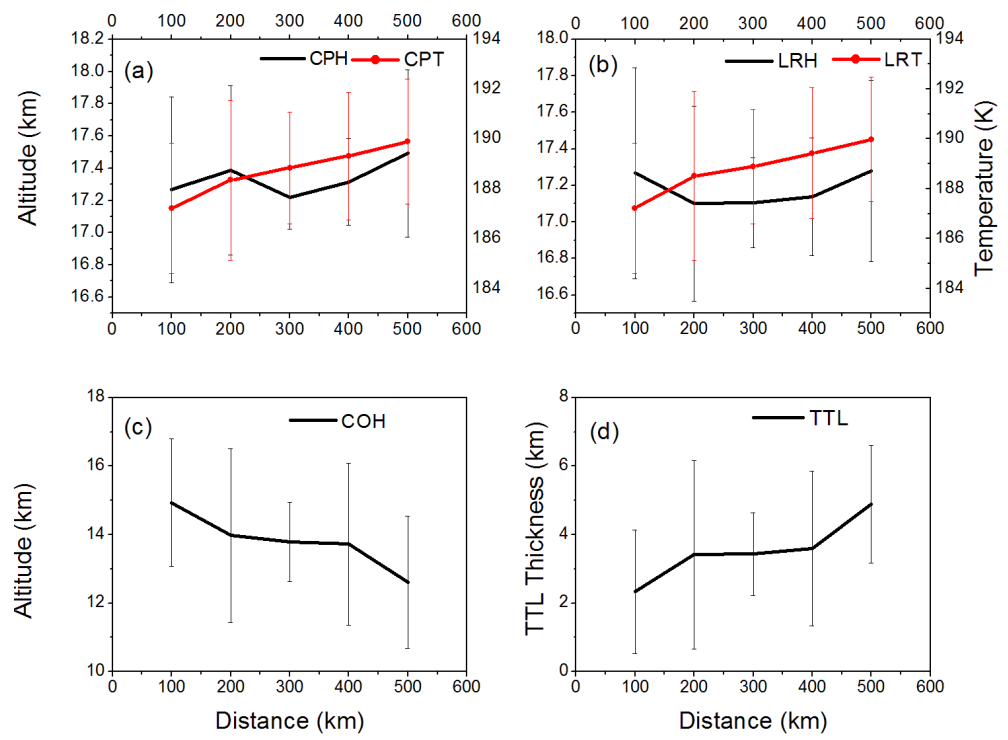

Figure 8. Variability in the tropopause parameters of (a) CPH and CPT, (b) LRH and LRT, (c) COH, and (d) TTL thickness observed within $500 \mathrm{~km}$ from the centre of the TC. Vertical bars show the standard error.

ticed (Fig. 8c) when we move away from the TC centre leading to the increase in the TTL thickness of $3 \mathrm{~km}$ (Fig. 8d). Note that a lowering of CPH (may be due to the presence of subsidence and strong downdrafts) in the eye region and higher $\mathrm{COH}$, leading to a lowering of TTL thickness within $100 \mathrm{~km}$ from the TC centre is again evident. Most of the overshooting convection may occur within $200 \mathrm{~km}$ and the top of the convection may be lifting the tropopause higher. An additional $1 \mathrm{~km}$ lowering of the TTL thickness within $100 \mathrm{~km}$ when compared to $500 \mathrm{~km}$ away from the TC centre mainly comes from a lowering of CPH. Thus, a decrease in TTL thickness is the combination of the pushing up of $\mathrm{COH}$ and a lowering of $\mathrm{CPH}$.

\section{Summary and conclusions}

In the present communication, we investigated and quantified the effects of tropical cyclones that occurred between 2007 and 2013 on the tropical tropopause parameters obtained from simultaneous high vertical resolution and high accuracy COSMIC GPS RO measurements. TCs are categorized, based on the intensity of their effect on the thermal structure and thus tropopause parameters are different for different intensities. Out of 44 cyclones that originated over the $\mathrm{BoB}$ and the AS, the investigation is carried out on $16 \mathrm{cy}-$ clones which have lifetimes of 4 days or more. The TC centre is fixed, based on the best tracks data available from the IMD at $3 \mathrm{~h}$ intervals. GPS RO overpasses that occurred within a radius of $1000 \mathrm{~km}$ of the centre of the TC are separated. Tropical tropopause parameters are estimated for each individual profile that occurred at various distances within $1000 \mathrm{~km}$ and are grouped for every $250 \mathrm{~km}$ radius from the centre of the
TC. They are further separated based on the intensity of the TC. In order to make quantitative estimates of the effect of TCs on the tropopause parameters, individual tropopause parameters obtained during TC are removed from the climatological mean tropopause parameters that are obtained by averaging the GPS RO measurements available from 2002 to 2013 (CHAMP and COSMIC). The effect of TCs on the vertical distribution of water vapour obtained from COSMIC GPS RO is also investigated. Again GPS RO overpasses that occurred within a radius of $500 \mathrm{~km}$ of the TC centre within $\pm 1 \mathrm{~h}$ for every $3 \mathrm{~h}$ are separated for every 100, 200,300,400, and $500 \mathrm{~km}$ from the centre of the TC. Finally, detailed investigations are made to see the effect of TCs on the tropopause parameters within $500 \mathrm{~km}$ from the centre of the TC. The main findings of the present study are summarized as follows.

1. In general, the $\mathrm{CPH}(\mathrm{LRH})$ is lowered by $0.6 \mathrm{~km}$ $(0.4 \mathrm{~km})$ in most of the areas within a $1000 \mathrm{~km}$ radius of the TC centre and CPT (and LRT) is colder by 3$4 \mathrm{~K}$. $\mathrm{COH}$ is increased up to $2 \mathrm{~km}$ and TTL thickness is reduced by $2 \mathrm{~km}$ within $500 \mathrm{~km}$ from the TCs and in some areas, up to $1000 \mathrm{~km}$.

2. CPH (CPT) increases (decreases) as we move away from the TC centre within $500 \mathrm{~km}$. There is a difference of $0.4 \mathrm{~km}(3 \mathrm{~K})$ in the CPH (CPT) within $500 \mathrm{~km}$ from the centre of the TC. Similar variability is observed in the LRT but not in LRH. An inverse relation between LRH and LRT is noticed but not in CPH and CPT. A nearly $2 \mathrm{~km}$ decrease in $\mathrm{COH}$ is clearly noticed when we move away from the TC centre, leading to a total increase in the TTL thickness of $3 \mathrm{~km}$ within $500 \mathrm{~km}$. 
3. The decrease in TTL thickness within $500 \mathrm{~km}$ from the TC centre is not only because of the pushing up of the $\mathrm{COH}$ but also because of the decrease of $\mathrm{CPH}$.

4. Higher RH is evident within $500 \mathrm{~km}$ from the TC centre, reaching as high as $15 \mathrm{~km}$. Thus, it is clear that deep convection prevailing within $500 \mathrm{~km}$ from the centre of the TC can penetrate to the lower stratosphere through the tropopause.

5. In general, no significant difference in the temperature structure within $500 \mathrm{~km}$ from the TC centre is noticed below $14 \mathrm{~km}$; however, large variation in the mean temperature structure is noticed above $14 \mathrm{~km}$. There is a temperature difference of $5 \mathrm{~K}$ in the UTLS region between the profiles that occur within $100 \mathrm{~km}$ and the profiles that occurred within $500 \mathrm{~km}$.

6. Multiple tropopause structures are also visible in the profiles that occurred within $100 \mathrm{~km}$ from the TC.

7. The colder tropopause temperatures are clearly observed within $1000 \mathrm{~km}$ in the case of CPT and throughout $1000 \mathrm{~km}$ on the eastern side in the case of LRT. In general, larger $\mathrm{RH}$ values are noticed on the southeastern side of the TCs in the lower layer $(0-5 \mathrm{~km})$, but throughout the south side of the TC in the $5-10 \mathrm{~km}$ layer. Higher RH values of $70 \%$ or more are noticed on the eastern side of the TC in the $10-15 \mathrm{~km}$ layer. Interestingly $\mathrm{COH}$ is much higher over $1000 \mathrm{~km}$ and also towards the south side of the TC centre, with maximum altitude of around $15 \mathrm{~km}$, leading to a lesser TTL thickness. TTL thickness is less than $3 \mathrm{~km}$ within $500 \mathrm{~km}$ from the centre of the TC and up to $1000 \mathrm{~km}$ on the southern side.

Thus, this study clearly demonstrated that the TCs can significantly affect the tropical tropopause, and the effects are more pronounced within $500 \mathrm{~km}$ from the centre of the TC. It will be interesting to see the ozone variability in the upper troposphere and water vapour in the lower stratosphere using satellite observations at the same time and hence STE processes during the TC will be investigated in our future work. Further, in the present study we are unable to make quantitative estimates of the tropopause parameters' variability during different stages (time series) of the cyclone due to sparse data of existing GPS RO observations. Once data are available from the other similar payload (the ROSA onboard the Megha-Tropiques) launched in 2011 in low inclination and from the forthcoming COSMIC-2, which will have six low earth orbit GPS receivers to be launched in low inclination in the first half of 2016, we will be able to quantity the effects more effectively.
Acknowledgements. We would like to thank COSMIC Data Analysis and Archive Centre (CDAAC) for providing GPS RO data used in the present study through their FTP site. The provision of tropical cyclone best track data used in the present study by IMD through their website is highly acknowledged. This work is done as a part of CAWSES India Phase-II Theme 3, fully supported by Indian Space research organization.

Edited by: P. Haynes

\section{References}

Anthes, R. A., Bernhardt, P. A., Chen, Y., Cucurull, L., Dymond, K. F., Ector, D., Healy, S. B., Ho, S.-H., Hunt, D. C., Kuo, Y.-H., Liu, H., Manning, K., McCormick, C., Meehan, T. K., Randel, W. J., Rocken, C., Schreiner, W. S., Sokolovskiy, S. V., Syndergaard, S., Thompson, D. C., Trenberth, K. E., Wee, T.-K., Yen, N. L., and Zeng, Z.: The COSMIC/Formosat/3 mission: Early results, B. Am. Meteorol. Soc., 89, 313-333, 2008.

Biondi, R., Neubert, T., Syndergaard, S., and Nielsen, J. K.: Radio occultation bending angle anomalies during tropical cyclones, Atmos. Meas. Tech., 4, 1053-1060, doi:10.5194/amt-4-10532011, 2011.

Biondi, R., Randel, W. J., Ho, S.-P., Neubert, T., and Syndergaard, S.: Thermal structure of intense convective clouds derived from GPS radio occultations, Atmos. Chem. Phys., 12, 5309-5318, doi:10.5194/acp-12-5309-2012, 2012.

Biondi, R., Ho, S. P., Randel, W., Syndergaard, S., and Neubert, T.: Tropical cyclone cloud-top height and vertical temperature structure detection using GPS radio occultation measurements, J. Geophys. Res.-Atmos., 118, 5247-5259, doi:10.1002/jgrd.50448, 2013.

Biondi, R., Steiner, A. K., Kirchengast, G., and Rieckh, T.: Characterization of thermal structure and conditions for overshooting of tropical and extratropical cyclones with GPS radio occultation, Atmos. Chem. Phys., 15, 5181-5193, doi:10.5194/acp-15-51812015, 2015.

Cairo, F., Buontempo, C., MacKenzie, A. R., Schiller, C., Volk, C. M., Adriani, A., Mitev, V., Matthey, R., Di Donfrancesco, G., Oulanovsky, A., Ravegnani, F., Yushkov, V., Snels, M., Cagnazzo, C., and Stefanutti, L.: Morphology of the tropopause layer and lower stratosphere above a tropical cyclone: a case study on cyclone Davina (1999), Atmos. Chem. Phys., 8, 34113426, doi:10.5194/acp-8-3411-2008, 2008.

Corti, T., Luo, B. P., deReus, M., Brunner, D., Cairo, F., Mahoney, M. J., Matucci, G., Matthey, R., Mitev, V., dos Santos, F. H., Schiller, C., Shur, G., Sitnikov, N. M., Spelten, N., Vossing, H. J., Borrmann, S., and Peter, T.: Unprecedented evidence for overshooting convection hydrating the tropical stratosphere, Geophys. Res. Lett., 35, L10810, doi:10.1029/2008GL033641, 2008.

Danielsen, E. F.: In situ evidence of rapid, vertical, irreversible transport of lower tropospheric air into the lower tropical stratosphere by convective cloud turrets and by larger-scale upwelling in tropical cyclones, J. Geophys. Res., 98, 8665-8681, doi:10.1029/92JD02954,1993.

Das, S. S., Venkat Ratnam, M., Uma, K. N., Patra, A. K., Subrahmanyam, K. V., Girach, I. A., Aneesh, S., Sijikumar, S., Kumar, K. K., Suneeth, K. V., and Ramkumar, G.: Stratosphere- 
troposphere exchange during the tropical cyclone Nilam, Atmos. Chem. Phys. Discuss., submitted, 2015.

Davis, C. A., Ahijevych, D. A., Haggerty, J. A., and Mahoney, M. J.: Observations of Temperature in the Upper Troposphere and Lower Stratosphere of Tropical Weather Disturbances, J. Atmos. Sci., 71, 1593-1608, doi:10.1175/JAS-D-13-0278.1, 2014.

Emanuel, K. A.: Increasing destructiveness of tropical cyclones over the past 30 years, Nature, 436, 686-688, doi:10.1038/nature03906, 2005.

Emanuel, K. A.: Downscaling CMIP5 climate models shows increased tropical cyclone activity over 21 st century, P. Natl. Acad. Sci. USA, 110, 12219-12224, 2013.

Fueglistaler, S., Dessler, A. E., Dunkerton, T. J., Fu, I., Folkins, Q., and Mote, P. W.: Tropical tropopause layer, Rev. Geophys., 47, RG1004, doi:10.1029/2008RG000267, 2009.

Gettelman, A. and Birner, T.: Insights into tropical tropopause layer processes using global models, J. Geophys. Res., 112, D23104, doi:10.1029/2007JD008945, 2007.

Gettelman, A. and Forster, P. M. F.: A climatology of the tropical tropopause layer, J. Meteorol. Soc. Jpn., 80, 911-924, doi:10.2151/jmsj.80.911, 2002.

Highwood, E. J. and Hoskins, B. J.: The tropical tropopause, Q. J. Roy. Meteorol. Soc., 124, 1579-1604, doi:10.1002/qj.49712454911, 1998.

Holton, J. R., Haynes, P. H., McIntyre, M. E., Douglass, A. R., Rood, R. B., and Pfister, L.: Stratosphere Troposphere exchange, Rev. Geophys., 33, 403-439, doi:10.1029/95RG02097, 1995.

Kishore, P., Venkat Ratnam, M., Namboothiri, S. P., Velicogna, I., Basha, G., Jiang, J. H., Igarashi, K., Rao, S. V. B., and Sivakumar, V.: Global $\left(50^{\circ} \mathrm{S}-50^{\circ} \mathrm{N}\right)$ distribution of water vapor observed by COSMIC GPS RO: Comparison with GPS radiosonde, NCEP, ERA-Interim and JRA-25 reanalysis data sets, J. Atmos. Sol.-Terr. Phy., 73, 1849-1860, doi:10.1016/j.jastp.2011.04.017, 2011.

Koteswaram, P.: On the structure of hurricanes in the upper troposphere and lower stratosphere, Mon. Weather Rev., 95, 541-564, 1967.

Kuo, Y.-H., Wee, T.-K., Sokolovskiy, S., Rocken, W., Schreiner, W., Hunt, H., and Anthes, R. A.: Inversion and Error Estimation of GPS Radio Occultation Data, J. Meteorol. Soc. Jpn., 82, 507531,2004

Kursinski, E. R., Hajj, G. A., Schofield, J. T., Linfield, R. P., and Hardy, K. R.: Observing Earth's atmosphere with radio occultation measurements using the Global Positioning System, J. Geophys. Res., 102, 23429-23465, 1997.

Mehta, S. K., Krishna Murthy, B. V., Rao, D. N., Ratnam, M. V., Parameswaran, K., Rajeev, K., Raju, C. S., and Rao, K. G.: Identification of tropical convective tropopause and its association with cold point tropopause, J. Geophys. Res., 113, D00B04, doi:10.1029/2007JD009625, 2008.
Mehta, S. K., Venkat Ratnam, M., and Krishna Murthy, B. V.: Multiple tropopauses in the tropics: A cold point approach, J. Geophys. Res., 116, D20105, doi:10.1029/2011JD016637, 2011.

Midya, S. K., Dey, S. S., and Chakraborty, B.: Variation of the total ozone column during tropical cyclones over the Bay of Bengal and the Arabian Sea, Meteorol. Atmos. Phys., 117, 63-71, 2012.

Pattnaik, D. R. and Rama Rao, Y. V.: Track Prediction of very sever cyclone "Nargis" using high resolution weather research forecasting (WRF) model, J. Earth Syst. Sci., 118, 309-329, 2008.

Penn, S.: Ozone and temperature structure in a Hurricane, J. Appl. Meteorol., 4, 212-216, 1965.

Pommereau, J.-P. and Held, G.: Is there a stratospheric fountain?, Atmos. Chem. Phys. Discuss., 7, 8933-8950, doi:10.5194/acpd7-8933-2007, 2007.

Randel, W. J., Wu, F., and Gaffen, D.: Interannual variability of the tropical tropopause derived from radiosonde data and NCEP reanalysis, J. Geophys. Res., 105, 15509-15524, 2000.

Rao, D. N., Ratnam, M. V., Mehta, S., Nath, D., Ghouse Basha, S., Jagannadha Rao, V. V. M., Krishna Murthy, B. V., Tsuda, T., and Nakamura, K.: Validation of the COSMIC radio occultation data over Gadanki (13.48 N, 79.2 E): A tropical region, Terr. Atmos. Ocean. Sci., 20, 59-70, doi:10.3319/TAO.2008.01.23.01(F3C), 2009.

Ray, E. A. and Rosenlof, K. H.: Hydration of the upper tropopsphere by tropical cyclones, J. Geophys. Res., 112, D12311, doi:10.1029/2006JD008009, 2007.

Romps, D. M. and Kuang, Z. M.: Overshooting convection in tropical cyclones, Geophys. Res. Lett., 36, L09804, doi:10.1029/2009GL037396, 2009.

Schreiner, W., Rocken, C., Sokolovskiy, S., Syndergaard, S., and Hunt, D.: Estimates of the precision of GPS radio occultations from the COSMIC/FORMOSAT-3 mission, Geophys. Res. Lett., 34, L04808, doi:10.1029/2006GL027557, 2007.

Seidel, D. J., Ross, R. J., Angell, J. K., and Reid, G. C.: Climatological characteristics of the tropical tropopause as revealed by radiosondes, J. Geophys. Res., 106, 7857-7878, 2001.

Škerlak, B., Sprenger, M., and Wernli, H.: A global climatology of stratosphere-troposphere exchange using the ERA-Interim data set from 1979 to 2011, Atmos. Chem. Phys., 14, 913-937, doi:10.5194/acp-14-913-2014, 2014.

Venkat Ratnam, M., Tsuda, T., Shiotoani, M., and Fujiwara, M.: New Characteristics of the Tropical Tropopause Revealed by CHAMP/GPS Measurements, Scientific Online Letters of Atmosphere, 1, 185-188, doi:10.2151/sola.2005-048, 2005.

Waco, D. E.: Temperatures and turbolence at tropopause levels over hurricane Beula, Mon. Weather Rev., 98, 749-755, 1970.

Webster, P. J., Holland, G. J., Curry, J. A., and Chang, H.-R.: Changes in Tropical Cyclone Number, Duration, and Intensity in a Warming Environment, Science, 309, 1844-1846, 2005.

World Meteorological Organization (WMO): Meteorology-A three dimensional science, WMO Bull., 6, 134-138, 1957. 